\title{
Phytoplankton carbon isotope fractionation during a diatom spring bloom in a Norwegian fjord
}

\author{
H. Kukert*, U. Riebesell**
}

Alfred Wegener Institute for Polar and Marine Research, Postfach 1201 61, D-27515 Bremerhaven, Germany

\begin{abstract}
The stable carbon isotope composition $\left(\delta^{13} \mathrm{C}\right)$ of particulate organic carbon (POC) was measured in 3 size fractions ( $\mathrm{POC}_{\text {total, }}$ POC $\mathrm{PO}_{20} \mathrm{\mu m}, \mathrm{POC}_{<20 \mu \mathrm{m}}$ ) during a phytoplankton spring bloom dominated by the diatom Skeletonema costatum in Lindăspollene, a land-locked fjord in southern Norway. In addition to standard parameters for characterizing the phytoplankton bloom (chlorophyll, nutrient, and $\mathrm{POC}$ concentrations, and species composition), simultaneous measurements of $\delta^{13} \mathrm{C}$ of dissolved inorganic carbon (DIC), total alkalinity and DIC concentration were obtained to determine temporal trends in dissolved carbon dioxide concentration and in carbon isotope fractionation $\left(\varepsilon_{p}\right)$ of the POC size fractions. The carbon isotope composition of the $>20 \mu \mathrm{m}$ size fraction, which was dominated by diatoms, was ca $2 \%$ heavier than that of the $<20 \mu \mathrm{m}$ fraction, which was mainly composed of flagellates. $8^{13} \mathrm{C}$ of both size fractions increased by about $3 \%$ over the course of the bloom. A $5 \%$ increase in $\delta^{13} \mathrm{C}-\mathrm{POC}$ total during the bloom resulted partly from a shift in the phytoplankton community from a flagellate- to a diatom-dominated one. Carbon isotope fractionation of all fractions decreased with declining $\mathrm{CO}_{2}(\mathrm{aq})$ concentration $\left(14\right.$ to $>6 \mu \mathrm{mol} \mathrm{I}^{-1}$ ). A positive correlation between $\varepsilon_{\mathrm{p}}$ and $\left[\mathrm{CO}_{2}(\mathrm{aq})\right]$ in the diatom size fraction was obtained for the period of exponential growth. Deviation from this correlation occurred after the peak in cell density and chlorphyll a (chl a) concentration, when POC still continued to increase, and may be related to changing phytoplankton growth rates or to possible effects of nutrient (nitrate) limitation on $\varepsilon_{p}$. Comparison of these results with those of previous field studies shows that, while an inverse relationship is consistently observed between $\varepsilon_{p}$ and the ratio of instantaneous growth rate and $\mathrm{CO}_{2}$ concentration $\left\{\mu_{\mathrm{i}} /\left[\mathrm{CO}_{2}(\mathrm{aq})\right]\right\}$, considerable scatter exists in this relationship. While this scatter may have partly resulted from inconsistencies between the different studies in estimating phytoplankton growth rate, it could also reflect that factors other than growth rate and $\mathrm{CO}_{2}$ concentration significantly contribute to determining isotope fractionation by marine phytoplankton in the natural environment.
\end{abstract}

KEY WORDS: $\delta^{13} \mathrm{C} \cdot$ lsotope fractionation $\cdot \mathrm{CO}_{2} \cdot$ Phytoplankton $\cdot$ Diatom bloom

\section{INTRODUCTION}

The realization that the carbon isotope composition, $\delta^{13} \mathrm{C}$, of terrestrial plants is largely determined by discrimination of the carbon-fixing enzyme Ribulose-1,5bisphosphate-carboxylase-oxygenase against ${ }^{13} \mathrm{CO}_{2}$ (Park \& Epstein 1960) was the crucial step that tied plant isotopic composition to properties of the environment, such as $\mathrm{CO}_{2}$ concentration. Degens et al. (1968) were the first to experimentally demonstrate a positive relationship between photosynthetic discrimination

\footnotetext{
- Deceased

-.E-mail: uriebesell@awi-bremerhaven.de
}

against ${ }^{13} \mathrm{CO}_{2}$ and the concentration of molecular dissolved carbon dioxide, $\left[\mathrm{CO}_{2}(\mathrm{aq})\right]$, in marine phytoplankton. This relationship was applied by Degens (1969) to interpret low $\delta^{13} \mathrm{C}$ values of organic matter from ancient marine sediments as being the result of high $\mathrm{CO}_{2}$ (aq) concentrations at the time of formation. A close correlation between carbon isotope composition of particulate organic carbon and $\mathrm{CO}_{2}$ (aq) concentration was further substantiated for the contemporary ocean, and applied to hindcast the atmospheric partial pressure of $\mathrm{CO}_{2}$ from plankton $\delta^{13} \mathrm{C}$ of cretaceous sediments (Rau et al. 1989). Meanwhile, laboratory evidence has been accumulating to support a positive relationship between photosynthetic carbon isotope 
discrimination, $\varepsilon_{\mathrm{p}}$, and $\left[\mathrm{CO}_{2}(\mathrm{aq})\right]$ of the medium (e.g. Pardue et al. 1976, Mizutani \& Wada 1982, Hinga et al. 1994, Laws et al. 1995, 1997, Bidigare et al. 1997, Popp et al. 1998).

Aside from growing evidence that $\varepsilon_{\mathrm{p}}$ and $\left[\mathrm{CO}_{2}(\mathrm{aq})\right]$ may be positively related, other laboratory data suggest that physical factors such as temperature (e.g. Wong \& Sackett 1978, Hinga et al. 1994, Johnston 1996), pH (Hinga et al. 1994), salinity (Leboulanger et al. 1995), light intensity (Korb et al. 1996) and daylength (Leboulanger et al. 1995) may also influence phytoplankton $\varepsilon_{\mathrm{p}}$. In addition, carbon demand as represented by growth rate (e.g. Fry \& Wainright 1991, Takahashi et al. 1991, Laws et al. 1995, 1997), variation in the inorganic carbon source, i.e. $\mathrm{CO}_{2}(\mathrm{aq})$ versus bicarbonate (Degens et al. 1968), passive diffusion versus active uptake of inorganic carbon (Sharkey \& Berry 1985, Raven et al. 1993), differences in the carboxylating enzyme (Robinson \& Cavanaugh 1995) and $\beta$-carboxylation reactions (Descolas-Gros \& Fontugne 1990, Falkowski 1991) may cause significant variation in $\varepsilon_{\mathrm{p}}$. To complete this list, phytoplankton species-specific differences (Wong \& Sackett 1978, Falkowski 1991, Korb et al. 1996) and differences in nutrient utilization, i.e. $\mathrm{NO}_{3}{ }^{-}$versus $\mathrm{NH}_{4}{ }^{+}$use (Guy et al. 1993), have been suggested to affect $\varepsilon_{\mathrm{p}}$.

Among the numerous factors experimentally shown to influence phytoplankton isotope fractionation, not all are necessarily relevant under natural conditions in the field and only a few are likely to exert significant control at any given time and location. In order to iden-

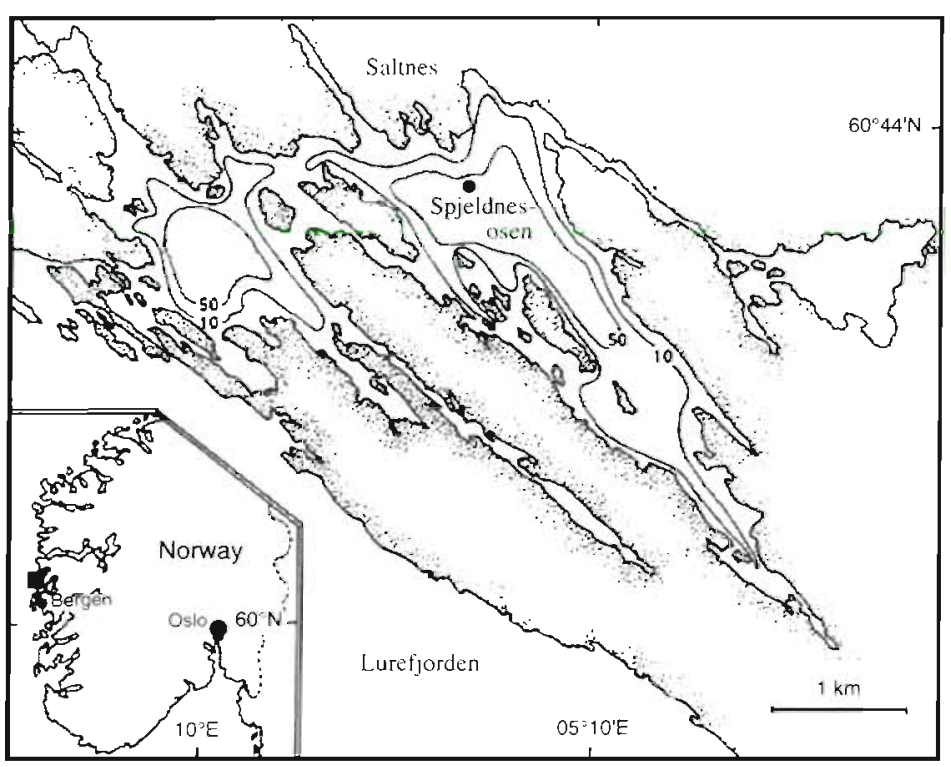

Fig. 1. Location of the sampling station in Lindasspollene. Inset map shows location o: Lindasspollene $(\mathbb{\square})$ in southern Norway (modified after Aksnes \& Lie 1990) tify the relevant parameters determining isotope fractionation in the field, it is therefore necessary to relate organic matter $\delta^{13} \mathrm{C}$ to the environmental conditions under which it was produced. Vertical transport of particulate organic matter and its incorporation into sediments occurs to a large extent in episodic events often related to phytoplankton blooms (Berger \& Wefer 1990). For the interpretation of sedimentary organic matter $\delta^{13} \mathrm{C}$, it is of particular interest, therefore, to monitor organic matter isotope composition during bloom formation. Periods of bloom development, however, are generally characterized by systematic trends in environmental parameters which in themselves may affect the isotopic signal of the accumulating biomass. The intention of the present study, therefore, is to obtain synoptic information on the relationship between organic matter $\delta^{13} \mathrm{C}$ and changing environmental conditions during the course of a phytoplankton bloom.

\section{MATERIALS AND METHODS}

Location. Lindåspollene is a land-locked fjord ca $40 \mathrm{~km}$ north of Bergen., Norway (Fig. 1), known for an annual spring bloom that is generally dominated by the diatom Skeletonema costatum (e.g. Lännergren \& Skjoldal 1976, see Aksnes \& Lie 1990 for further references). Lindảspollene consists of 3 basins with a maximum depth of $90 \mathrm{~m}$ which are separated by shallow sills. The connection to the outer fjord, the Lurefjorden, is maintained by 3 shallow sills less than $3 \mathrm{~m}$ deep. The glacier-free watershed has an area of ca $35 \mathrm{~km}^{2}$ and provides $70 \times 10^{6} \mathrm{~m}^{3}$ freshwater annually to the fjord, which amounts to about half of its volume (Wassmann 1983). The tidal range is ca $50 \mathrm{~cm}$ and the concomitant water exchange during 1 tidal cycle is roughly $2 \%$ of the total volume (Wassmann 1983). The sampling station in the fjord was marked by a buoy,

Sampling. Sampling commenced in mid March of 1997, well betore the onset of the diatom bloom. Data reported here cover the period from April 4 to 14, 1997, during which the development of a bloom of the diatom Skeletonema costatum was followed. During this period sampling was conducted between 13:00 and 15:00 h from a small rowboat with an outboard engine. At the beginning of the sampling program, maximum chlorophyll a (chl a) concentrations were at ca $2 \mathrm{~m}$ depth. All data presented here are from samples taken at this depth. Water samples were obtained with a hand-operated, 2 I Ruttner 
sampler in bottles thoroughly rinsed with water from the sampling depth. Samples for isotopic composition of particulate organic carbon $\left(\delta^{13} \mathrm{C}-\mathrm{POC}\right)$, isotopic composition of dissolved inorganic carbon $\left(\delta^{13} \mathrm{C}\right.$-DIC $)$, dissolved inorganic carbon concentration ([DIC]), alkalinity, nutrients, and phytoplankton community composition were taken from the same cast, and the water was stored in $1 \mathrm{l}$ Schott flasks. Once ashore, samples for $\delta^{13} \mathrm{C}$-DIC, $[\mathrm{DIC}]$, alkalinity, and nutrients were fixed with mercury chloride $(2 \%)$, and those for phytoplankton community composition with Lugol's iodine (Edler 1979). Every second day, additional phytoplankton community samples were fixed with $20 \%$ hexamine-buffered formalin solution (Edler, 1979). Samples for chl $a$ and size-fractionated POC filtration were taken from repetitive casts to the same depth, stored in 1 l Schott flasks, and transported to the laboratory in a cooler for immediate filtration.

For temperature and conductivity (salinity) measurements $(0$ to $20 \mathrm{~m})$, we used a hand operated probe (WTW LF 191) with a cable marked at $1 \mathrm{~m}$ intervals. Vertical chl a profiles ( 0 to $20 \mathrm{~m}$ ) were obtained with an in situ fluorometer connected to a CTD (ADM) operating in storage mode.

Filtration. Samples for chl a determination were filtered onto glass-fiber filters (Whatman GF/C) and analyzed immediately. Samples for particulate organic matter (for later analysis of POC, PON [particulate organic nitrogen], and $\delta^{13} \mathrm{C}$-POC) were filtered onto glassfiber filters (Whatman $\mathrm{GF} / \mathrm{C}$ ) precombusted at $500^{\circ} \mathrm{C}$ for $12 \mathrm{~h}$. Material for $\delta^{13} \mathrm{C}$-POC was filtered in duplicate $(200$ to $500 \mathrm{ml})$ from the same cast as the liquid samples (i.e. $[\mathrm{DIC}], \delta^{i 3} \mathrm{C}$-DIC, etc.). For size fractionation of $\mathrm{POC}, 1$ to $5 \mathrm{l}$ of seawater from additional, repetitive casts was filtered through a $200 \mu \mathrm{m}$ gauze (to remove zooplankton) and a $20 \mu \mathrm{m}$ gauze, to obtain $\delta^{13} \mathrm{C}-\mathrm{POC}_{<20 u \mathrm{~m}}$ and $\delta^{13} \mathrm{C}-\mathrm{POC}_{>20 \mu \mathrm{m}}$ samples. The POC on the $20 \mu \mathrm{m}$ screen was washed off with $\mathrm{GF} / \mathrm{C}$ filtered seawater and filtered onto a glass-fiber filter. Except for the first $4 \mathrm{~d}, \delta^{13} \mathrm{C}-\mathrm{POC}_{>20} \mu \mathrm{m}$ samples were taken in duplicate; $\delta^{13} \mathrm{C}-\mathrm{POC}_{<20} \mathrm{\mu m}$ was always sampled without replicates. All filters were stored in glass petri dishes and frozen at $-20^{\circ} \mathrm{C}$. The petri dishes were initially cleaned with a detergent free of organic substances.

Measurements. Chl a concentration was determined fluorometrically (Turner 10-AU-005) according to Edler (1979). POC, PON and the carbon isotopic composition of particulate organic matter were measured on the same filters with a continuous flow isotope ratio mass spectrometer (Europa Scientific, ANCA SL 2020). Filters were thawed, acid fumed for $4 \mathrm{~h}$, dried for $12 \mathrm{~h}$ at $60^{\circ} \mathrm{C}$, and wrapped in Sn-vials prior to analysis. $\delta^{13} \mathrm{C}$-DIC was measured on a Finnegan MAT Delta-S isotope-ratio mass spectrometer after acidifying the sample in vacuo with orthophosphoric acid and cryogenically trapping the released $\mathrm{CO}_{2}$ (Mackensen et al. 1996). All values of carbon isotope composition are reported in $\delta$-notation relative to VPDB (Vienna PeeDee Belemnite).

DIC was determined coulometrically in duplicate with a system similar to that described by Johnson et al. (1987). In short, a defined volume of seawater is acidified with phosphoric acid, and the released carbon dioxide is bubbled into a titration cell and measured as electrons required to generate $\mathrm{OH}^{-}$ions to titrate the acid formed in the reaction of $\mathrm{CO}_{2}$ with ethanolamine. Alkalinities were titrated in duplicate with an automated, temperature-controlled system at $5^{\circ} \mathrm{C}$, and total alkalinity determined using the Granplot approach (Almgren et al. 1988). Inorganic nutrients were measured with an auto-analyzer (Technicon AA II) using the methods of Armstrong et al. (1967) for $\mathrm{NO}_{3}{ }^{-}$, Eberlein \& Kattner (1987) for $\mathrm{PO}_{4}{ }^{3-}$, and Grasshoff et al. (1983) for dissolved silica determination. Phytoplankton was identified, counted and measured ( $\mathrm{n} \geq 50$ for Skeletonema costatum) with an inverted microscope according to Utermöhl (1958).

Calculations. $\left[\mathrm{CO}_{2}(\mathrm{aq})\right]$ was calculated from total [DIC], alkalinity, salinity, temperature, and depth using dissociation constants of Goyet \& Poisson (1989). $\delta^{13} \mathrm{C} \mathrm{CO}_{2}(\mathrm{aq})$ was calculated from $\delta^{13} \mathrm{C}$-DIC measurements by combining the equations for ${ }^{13} \mathrm{C}$ fractionation between DIC and $\mathrm{CO}_{2}$ (gas), and $\mathrm{CO}_{2}(\mathrm{aq})$ and $\mathrm{CO}_{2}$ (gas) of Zhang et al. (1995, their Eqs. 2 \& 5 of Table 4). $\varepsilon_{p}$ was estimated using

$$
\varepsilon_{\mathrm{p}}=\frac{\delta^{13} \mathrm{C}_{\mathrm{CO}_{2}}-\delta^{13} \mathrm{C}_{\mathrm{POC}}}{1+\frac{\delta^{13} \mathrm{C}_{\mathrm{POC}}}{1000}}
$$

Standard error estimates for $\varepsilon_{\mathrm{p}}$ were calculated from the standard deviation of $\varepsilon_{\mathrm{p}}$ obtained using Gauss' law of error propagation (Kreyszig 1982) divided by the number of replicates.

Since recovery of the material collected on the $20 \mu \mathrm{m}$ screen was usually less than $100 \%$ (based on mass balance calculations $),[\mathrm{POC}]_{>20 \mu \mathrm{m}}$ was calculated as the difference of $[\mathrm{POC}]_{\text {total }}-[\mathrm{POC}]_{<20 \mu \mathrm{m}}$. Average growth rates $\left(u_{L+D} ; L\right.$ and $D$ : lengths of light and dark periods, respectively) were estimated independently from temporal changes in cell numbers of Skeletonema costatum and from changes in $[P O C]_{>20 \mu m}$ using least squares linear regression. Instantaneous growth rate $\left(\mu_{i}\right)$ was calculated according to

$$
\mu_{\mathrm{i}}=\frac{(L+D) \cdot \mu_{L+D}}{L-D \cdot r}
$$

which corrects $\mu_{L+D}$ for $L$ (cf. Laws et al. 1995, Rau et al. 1997). The average daylength during the study period was $13.7 \mathrm{~h}$. We assumed the ratio of dark respiration 

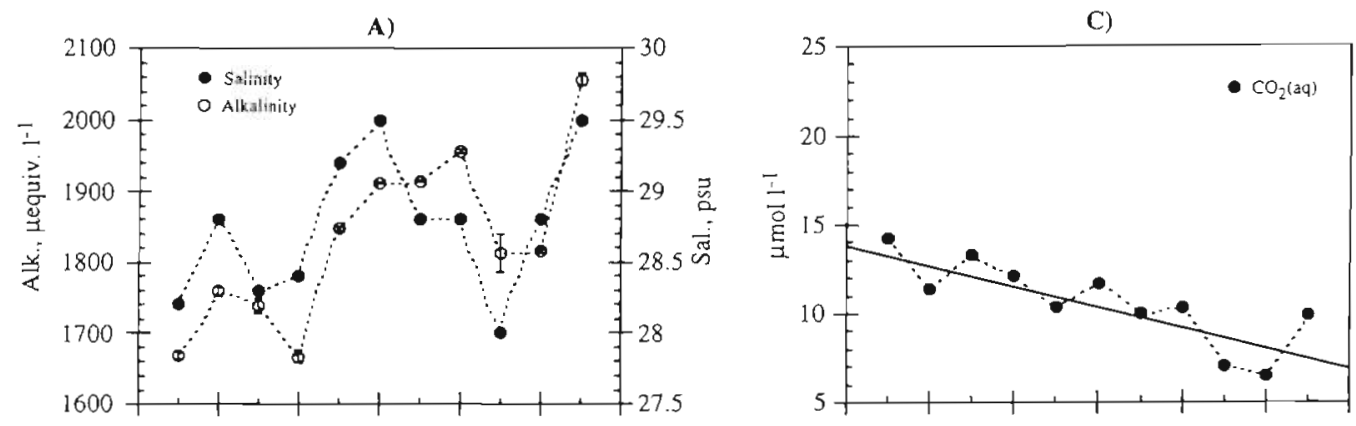

B)
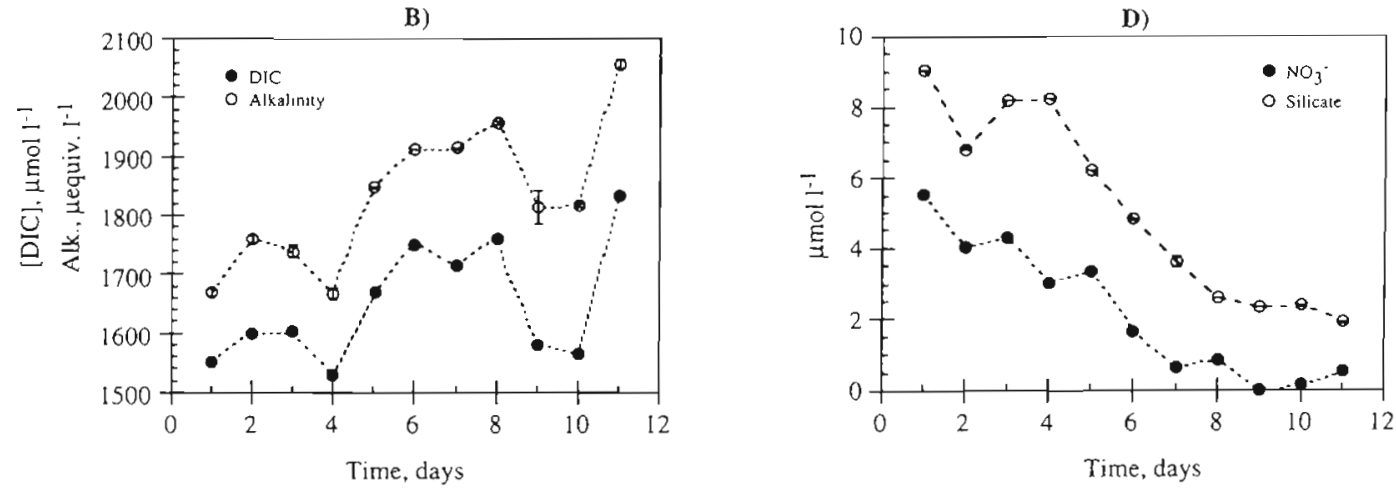

Fig. 2. (A) Salinity and alkalinity, (B) total dissolved inorganic carbon concentration, DIC, and alkalinity, (C) concentration of dissolved molecular carbon dioxide, $\mathrm{CO}_{2}(\mathrm{aq})$, and (D) concentrations of nitrate and silicate in Lindåspollene, Norway, during the sampling period. Error bars in alkalinity data represent $\pm 1 \mathrm{SD}$ between replicate measurements

rate to light carbon assimilation rate, $r$, to equal $15 \%$ for $D$ (Laws \& Bannister 1980, Geider \& Osborne 1989). The growth rate in the ratio $\mu_{1} /\left[\mathrm{CO}_{2}(\mathrm{aq})\right]$ was calculated with instantaneous growth rates obtained from temporal changes in $S$. costatum cell concentrations.

\section{RESULTS}

\section{Sampling station}

The sampling station was located roughly in the center of the inner basin (Spjeldnesosen) of Lindasspollene at a water depth of $65 \mathrm{~m}$ (Fig. 1). The upper $3 \mathrm{~m}$ were strongly stratified with temperature and salinity values ranging from 4.4 to $6^{\circ} \mathrm{C}$ and 21.6 to 29.2 practical salinity units (psu) at the surface; these values ranged from from 5 to $5.2^{\circ} \mathrm{C}$ and 29.2 to 29.8 psu at $3 \mathrm{~m}$ depth. Between 3 and $10 \mathrm{~m}$ depth the temperature varied between 5 and $5.1^{\circ} \mathrm{C}$, and the salinity increased steadily to approximately 31 psu.

\section{Inorganic measurements}

Over the sampling period, alkalinity showed a trend towards higher values, ranging from 1660 to
$2060 \mu \mathrm{eq} \mathrm{l}^{-1}$. Extreme values of alkalinity were correlated with extreme values of salinity (Fig. 2A), suggesting that the observed variability in alkalinity was driven by the mixing of different water masses.

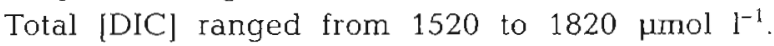
Observed variability in [DIC] closely correlated with that in alkalinity (Fig. $2 \mathrm{~B}) \cdot\left[\mathrm{CO}_{2}(\mathrm{aq})\right]$, calculated from alkalinity and [DIC], decreased from 14 to ca $6 \mu \mathrm{mol} \mathrm{l}^{-1}$ (Fig. 2C). Dissolved silicate concentrations decreased from 9 to $2 \mu \mathrm{mol} \mathrm{l}^{-1}$, while nitrate concentrations dimin-

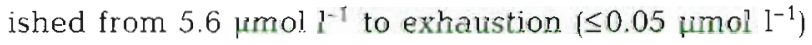
on Day 9 (Fig. 2D). Phosphate concentrations, not presented here, decreased from initially $0.47 \mu \mathrm{mol} \mathrm{I}^{-1}$ to a minimum value of $0.24 \mu_{\mathrm{mol} \mathrm{l}}^{-1}$ on Day 9. Although ammonium concentrations were not measured in this study, the observed drastic increase in the suspended organic matter $\mathrm{C} / \mathrm{N}$ ratio at the time of nitrate exhaustion (Fig. 3C) suggests that either ammonium concentrations were too low to compensate for nitrate deficiency or that ammonium was not effectively used by the bloom-forming phytoplankton.

\section{Plankton community}

The plankton community was composed of cryptophytes, choanoflagellates, chrysophytes (e.g. Apedi- 
nella spinifera), dinoflagellates (e.g. Gyrodinium sp. and Gymnodinium sp.), thecate and athecate smaller dinoflagellates, ciliates, and diatoms. Among the diatoms, Skeletonema costatum always dominated numerically, with 93 to $97 \%$ of the diatom abundance. The remaining 3 to $8 \%$ was comprised of Thalassiosira nordenskjöldii, Thalassionema nitzschioides, Pseudonitzschia cf, delicatissima and Chaetoceros spp. Size-fractionated filtration separated the POC into diatom-dominated POC (>20 $\mu \mathrm{m}$ fraction) and flagellate-dominated POC $(<20 \mu \mathrm{m}$ fraction $)$.

\section{Biological/organic measurements}

Chl a concentration and the abundance of Skeletonema costatum increased from 3 to $15 \mu \mathrm{g} \mathrm{l}^{-1}$ and from ca $4 \times 10^{5}$ to $1.9 \times 10^{7}$ cells I $^{-1}$, respectively, during Days 1 through 7 , and remained more or less constant thereafter (Fig. 3A). $[\mathrm{POC}]_{<20 \mu \mathrm{m}}$ varied between 200 and $500 \mu \mathrm{g} \mathrm{C}$ $1^{-1}$, with no consistent trend over the course of the bloom (Fig. 3B). In contrast, total [POC] and the calculated $[\mathrm{POC}]_{>20 \mu \mathrm{m}}$ increased drastically during bloom development from 301 to $1081 \mu \mathrm{g} \mathrm{Cl}^{-1}$ and from 54 to $759 \mu \mathrm{g} \mathrm{C}$ $\mathrm{I}^{-1}$, respectively. POC build-up continued until Day 10 , i.e. after chl a concentration and $S$. costatum cell numbers had reached their maximum (Fig. 3A, B). The carbon to nitrogen (molar) ratio of the suspended organic matter fractions $\left(\mathrm{POC}_{\text {total }}, \mathrm{POC}_{<20 \mu \mathrm{m}}\right.$, and $\mathrm{POC}_{>20 \mu \mathrm{m}}$ ) was minimal on Day 7 and increased to maximum values on Days 9 and 10 (Fig. 3C).

Average growth rate, $\mu_{L+D}$, estimated from Skeletonema costatum cell numbers over the period of exponential cell division (Days 1 through 7) was $0.57 \mathrm{~d}^{-1}$ $\left(r^{2}=0.996\right)$. Growth rate calculated from changes in $[P O C]_{>20 \mu m}$ over the period of exponential increase in $[\mathrm{POC}]_{>20 \mu \mathrm{m}}$ (i.e. Days 4 to 9 ) yielded a value of $0.52 \mathrm{~d}^{-1}\left(\mathrm{r}^{2}=0.967\right)$. Instantaneous growth rate, $\mu_{1}$, was $1.97 \mu_{L+D}$.

\section{Carbon isotopic composition}

$\delta^{13} \mathrm{C}$-DIC ranged from 0.75 to ca $1.6 \%$, with highest values on Days 9 and 10 (Fig. 4A) coinciding with the peak in total (POC) (Fig. 4B). Carbon isotopic composition of the 3 POC fractions $\left(\mathrm{POC}_{\text {total }}, \mathrm{POC}_{>20 \mu \mathrm{m}}\right.$ $\mathrm{POC}_{<20 \mu \mathrm{m}}$ ) increased with time (Fig. 4C). The size fraction $>20 \mu \mathrm{m}$ (dominated by diatoms) was roughly $2 \%$ heavier than the $<20 \mu \mathrm{m}$ fraction (dominated by flagellates). The diatom isotopic composition increased from -23 to $-20 \%$ and remained more or less constant after Day 7 . The $\delta^{13} \mathrm{C}$ of the flagellate-dominated fraction increased continuously from -24.6 to $-21.2 \%$. The isotopic composition of total POC increased by roughly

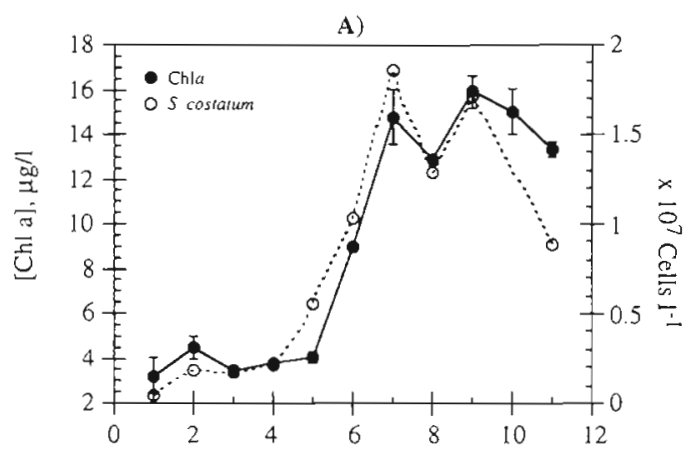

B)

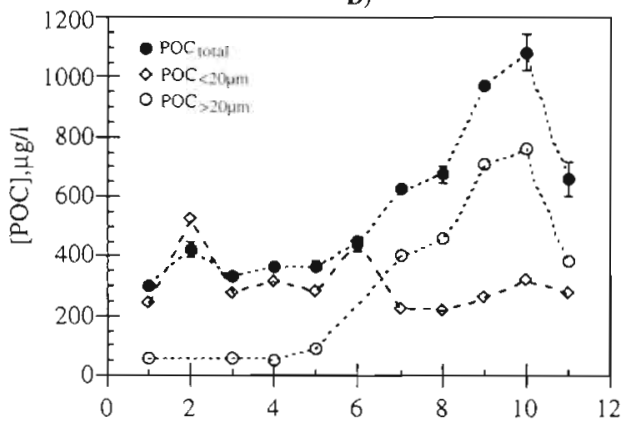

C)

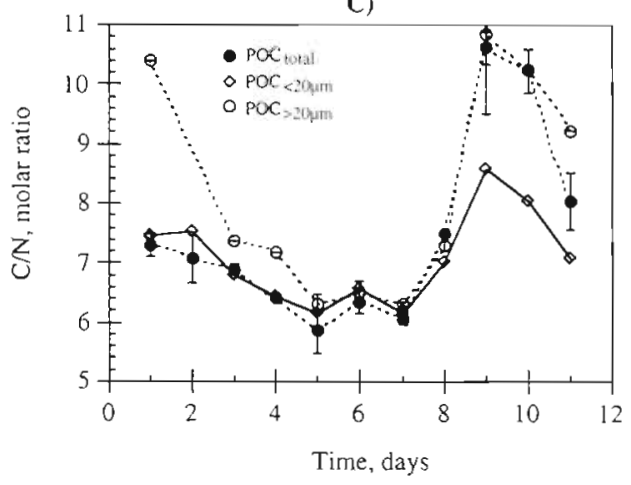

Fig. 3. (A) Concentration of chl a and abundance of Skeletonema costatum, (B) measured concentrations of $\mathrm{POC}_{\text {total }}$ and $\mathrm{POC}_{<20 \mu \mathrm{m}}$, and calculated concentrations of $\mathrm{POC}_{>20 \mu \mathrm{m}}$ and (C) measured molar carbon to nitrogen ratios of $\mathrm{POC}$ size fractions in Lindáspollene during the sampling period. Error bars show $\pm 1 \mathrm{SD}$

$5 \%$ from -25 to $-20 \%$. While initially $\delta^{13} \mathrm{C}$ of total POC was close to that of the $<20 \mu \mathrm{m}$ size fraction, it gradually shifted over the course of the bloom towards the isotopic composition of the diatom-dominated size fraction (>20 $\mathrm{mm}$, Fig. 4C).

\section{Carbon isotopic fractionation}

$\varepsilon_{\mathrm{p}}$ of the 3 size fractions ( $\mathrm{POC}_{\text {total }}, \mathrm{POC}_{>20 \mu \mathrm{m}}, \mathrm{POC}_{<20 \mu \mathrm{m}}$ ) was characterized by an overall decrease over the course of the bloom (Fig. 5A). A rapid decrease in $\varepsilon_{\mathrm{p}}$ of 

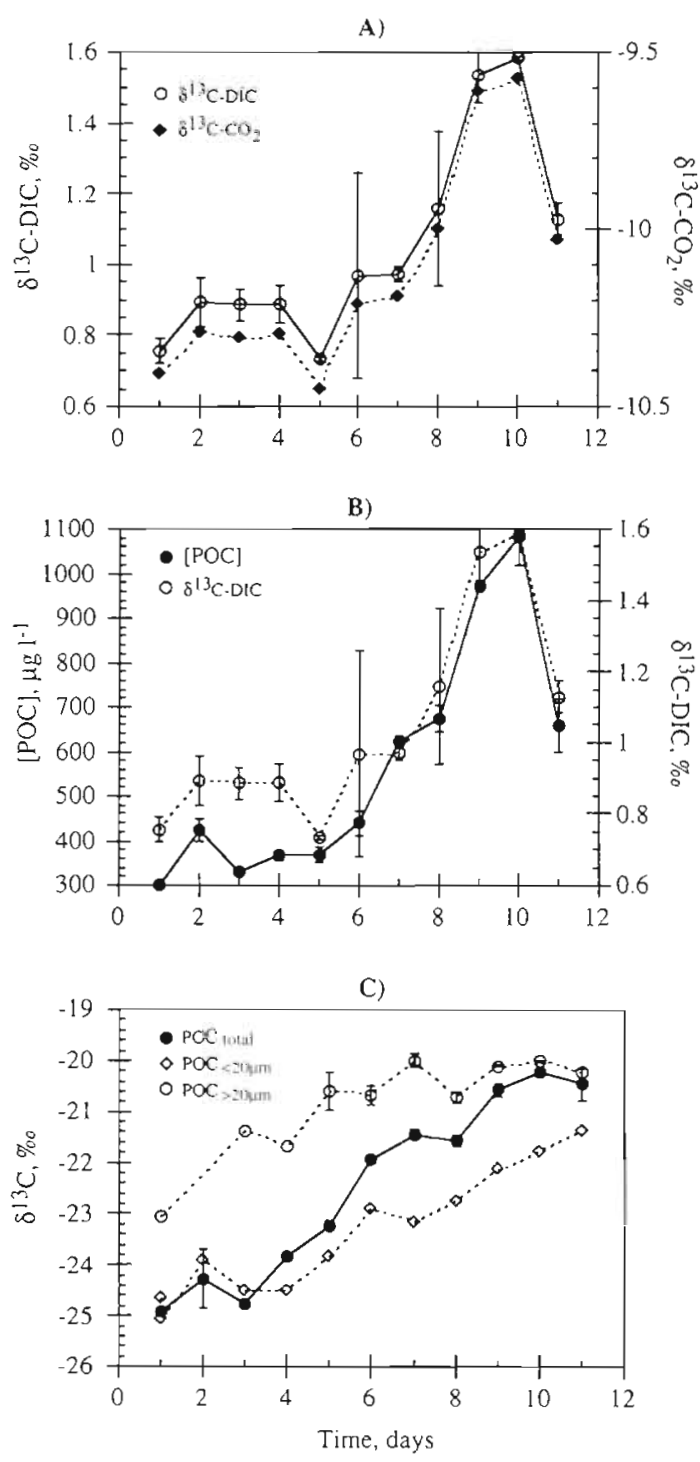

Fig. 4. (A) Carbon isotopic compositions of dissolved inorganic carbon, $\delta^{13} \mathrm{C}$-DIC (measured), and dissolved $\mathrm{CO}_{2}(\mathrm{aq})$, $\delta^{13} \mathrm{C}^{-\mathrm{CO}_{2}}$ (calculated); (B) POC concentration in relation to $\delta^{13} \mathrm{C}-\mathrm{DIC}$; and (C) stable carbon isotopic composition of total $\mathrm{POC}, \mathrm{POC}_{<20}, \mathrm{~m}$, and $\mathrm{POC}>20 \mu \mathrm{m}$ at Lindaspollene during the sampling period. $\mathrm{POC}_{>20 \mu \mathrm{m}}$ sample of Day 2 was lost during analysis (see also Fig. $5 \mathrm{~A}, \mathrm{~B}$ ). Error bars show $\pm 1 \mathrm{SD}$

both total POC and the diatom size fraction $\left(\mathrm{POC}_{>} 20 \mathrm{um}\right)$ occurred until Day 7, i.e. during the period of exponential increase in chl $a$ and cell abundance of Skeletonema costatum (Fig. 3A). Whereas $\varepsilon_{\mathrm{p}}$ of total POC and of the $<20 \mu \mathrm{m}$ size fraction continued to decrease until the end of the study, $\varepsilon_{p}$ values of the $>20 \mu \mathrm{m}$ fraction tended to level off after Day 7 , when $S$. costatum cell numbers had reached their maximum. Similarly, when plotted against $\mathrm{CO}_{2}$ concentration, $\varepsilon_{\mathrm{p}}$ of POC $>20 \mu \mathrm{m}$ decreased with $\left[\mathrm{CO}_{2}(\mathrm{aq})\right]$ during the development of the bloom and remained more or less con-

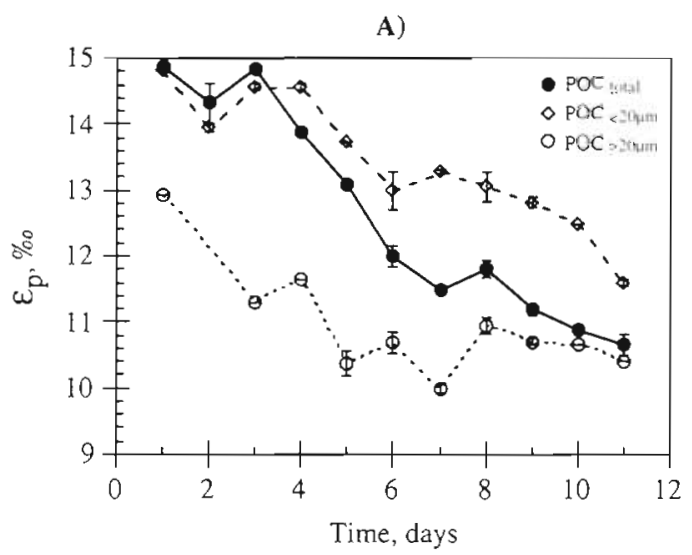

B)

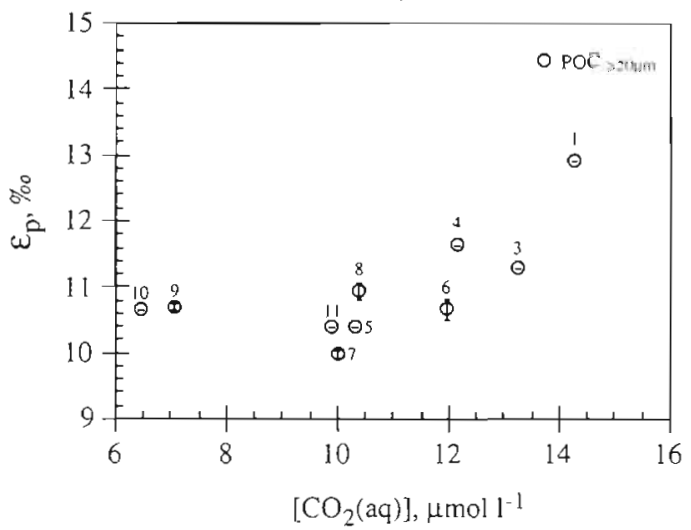

Fig. 5. (A) Carbon isotopic fractionation, $\varepsilon_{p}$, of total POC, $\mathrm{POC}_{>20 \mu \mathrm{m}}$, and $\mathrm{POC}_{<20 \text { um }}$ versus time and $(\mathrm{B}) \varepsilon_{\mathrm{p}}$ of $\mathrm{POC}_{>20 \mu \mathrm{m}}$ as a function of $\mathrm{CO}_{2}(\mathrm{aq})$ concentration. In (B), numbers indicate sampling day. Error bars show $\pm 1 \mathrm{SE}$

stant with declining $\left[\mathrm{CO}_{2}(\mathrm{aq})\right]$ during the following days (Fig. 5B).

An inverse linear relationship between $\varepsilon_{\mathrm{p}}$ and the ratio of cellular carbon demand to carbon supply represented by $\left.\mu_{4} /\left[\mathrm{CO}_{2}(\mathrm{aq})\right]\right\}$ is expected in cases of diffusive $\mathrm{CO}_{2}$ uptake (Laws et al. 1995, Rau et al. 1996). Such a relationship has been shown under laboratory conditions for a marine diatom culture at $\mu_{1} /\left[\mathrm{CO}_{2}(\mathrm{aq})\right]$ values < 0.3 (Laws et al. 1995) and has been found to deviate from linearity at values higher than 0.3 (Laws et al. 1997). Reliable estimates of the growth rate in the diatom $\left(\mathrm{POC}_{>20 \mathrm{\mu m}}\right)$ size fraction in this study are limited to the period of exponential growth, lasting from Days 1 to 7 . For this interval, the instantaneous growth rate calculated from cell concentrations was $\mu_{i}=$ $1.12 \mathrm{~d}^{-1}$. Using this number in an $\varepsilon_{\mathrm{p}}$ versus $\mu_{\mathrm{i}} /\left[\mathrm{CO}_{2}(\mathrm{aq})\right]$ plot also yields an inverse relationship for this data set (Fig. 6A), suggesting that the dependence of $\varepsilon_{\mathrm{p}}$ on the ratio of carbon demand to $\mathrm{CO}_{2}$ supply may also hold true for natural phytoplankton populations during the development of diatom blooms. 
A)

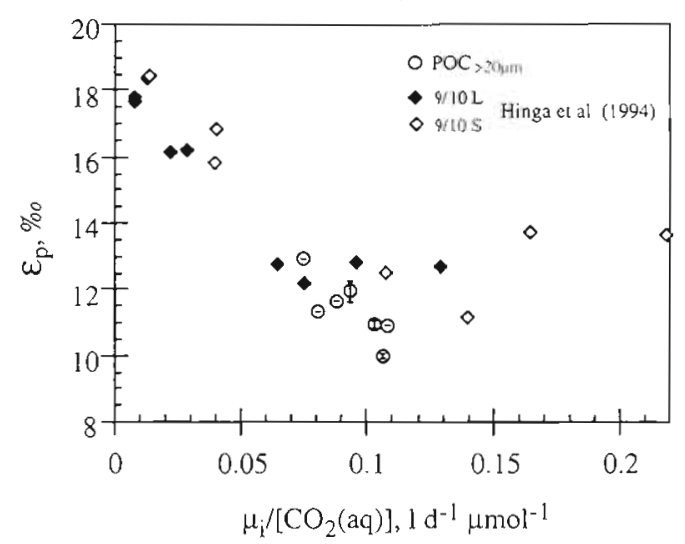

B)

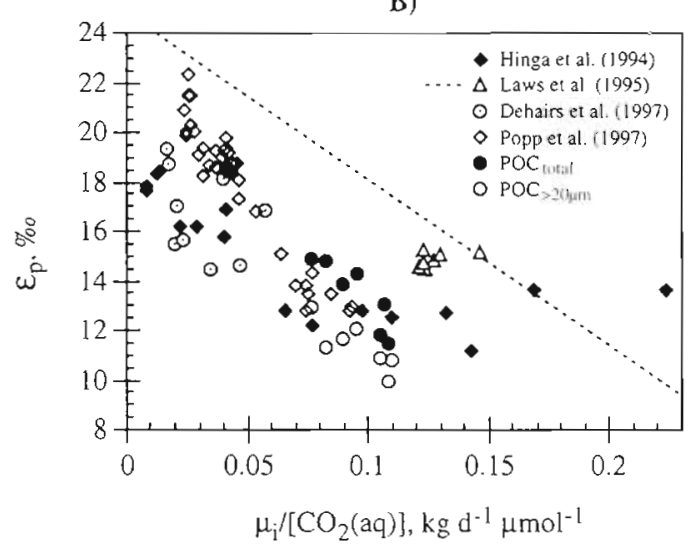

Fig. 6. (A) Carbon isotopic fractionation, $\varepsilon_{p}$, of $\mathrm{POC}_{>20 \mu \mathrm{m}}$ (dominated by Skeletonema costatum) versus the ratio of instantaneous growth rate and $\mathrm{CO}_{2}$ concentration, $\mu_{\mathrm{i}} /\left[\mathrm{CO}_{2}(\mathrm{aq})\right]$. Error bars show $\pm \mathrm{SE} .(\bullet, \diamond)$ Data of Hinga et al. (1994) obtained in culture experiments with Skeletonema costatum (experimental runs 9 and 10 incubated under full light [L] and shaded light [S] conditions). (B) Comparison of data from this study with laboratory results obtained by Hinga et al. (1994) and Laws et al. (1995; dashed line), and field results obtained by Laws et al. (1995; triangles), Dehairs et al. (1997), and Popp et al. (1997). $\varepsilon_{\mathrm{p}}$ estimates from field measurements are for total suspended particulate organic matter.

Note that $\mathrm{CO}_{2}(\mathrm{aq})$ concentrations in (B) are in $\mu \mathrm{mol} \mathrm{kg}{ }^{-1}$

\section{DISCUSSION}

\section{Lateral advection and temporal variability}

To investigate the temporal development of a phytoplankton bloom would ideally require repeated sampling within the same body of water. Due to lateral advection, this is rarely achieved in the natural environment if sampling is carried out at a fixed location. As indicated by significant changes in surface water salinity at the sampling site (Fig 2A), lateral advection also occurred during this study. Furthermore, total alkalinity and DIC both show considerable variability with time and correlate closely with salinity, indicating that the variability in these parameters may also be largely affected by lateral advection. This would imply that different water masses and hence different phytoplankton populations were sampled over the course of this study.

In contrast to salinity, alkalinity, and DIC, however, consistent temporal trends with little random variability were observed in biologically controlled parameters. Chl a concentration and the abundance of the dominant diatom species, Skeletonema costatum, for instance, both increased exponentially until the peak of the bloom, without any apparent variability corresponding to that observed in salinity (Fig. 3A). Similarly, a steady decline in inorganic nutrient concentrations, closely corresponding with the build-up of POC (Figs. 2D \& 3B), gives little indication of random variability due to lateral advection in these parameters. A close correlation was further obtained between $\delta^{13} \mathrm{C}$-DIC and POC concentration (Fig. 4B), whereby the ${ }^{13} \mathrm{C}$ enrichment in DIC corresponds closely to that expected from the amount and isotopic composition of POC built up during bloom development (roughly $0.8 \%$ increase in $\delta^{13} \mathrm{C}$-DIC for $65 \mu \mathrm{mol}$ $\mathrm{I}^{-1} \mathrm{POC}$ formed). These findings suggest that in spite of lateral advection at the sampling site, the phytoplankton populations sampled during the course of this study had experienced a similar life history. Changes in nutrient concentrations, phytoplankton biomass, $\delta^{13} \mathrm{C}$ of DIC and POC, $\varepsilon_{\mathrm{p}}$, etc. are therefore considered to primarily reflect the development of a phytoplankton bloom, and not changes in water masses.

The observed variability in $\mathrm{CO}_{2}$ concentration, on the other hand, may reflect at least partly the changes in DIC and alkalinity caused by lateral advection. Whereas both DIC and alkalinity varied by less than $20 \%$ over the study period with no consistent trend, $\left[\mathrm{CO}_{2}(\mathrm{aq})\right]$ decreased to about half of its pre-bloom concentration. This steady decline in surface water $\left[\mathrm{CO}_{2}(\mathrm{aq})\right]$ can be largely attributed to photosynthetic carbon fixation with its corresponding increase in seawater $\mathrm{pH}$.

On the last day of sampling the consistent trends between nutrient decline and [POC] build-up vanished. POC concentration and $\delta^{13} \mathrm{C}$-DIC dropped steeply and nitrate concentration increased (Figs. 2D \& $4 \mathrm{~B}$ ), suggesting that on this day a fundamentally different water mass entered the fjord. In fact, the strong northerly winds with velocities close to 30 knots that swept in on Day 11, are known to cause sudden changes in coastal water masses along the Norwegian coast (Sætre et al. 1988). 


\section{Temporal trends}

The temporal trends in nutrient concentrations and biological parameters suggest that we were indeed following the development of a phytoplankton bloom from the beginning until the end of the growth period. Skeletonema costatum abundance and chl a concentration increased exponentially until nitrate became the limiting nutrient, with concentrations dropping to $\leq 0.6 \mu \mathrm{mol} \mathrm{l}^{-1}$ (Eppley et al. 1969; Figs. 2D \& 3A). At this stage, on Day 7 , build-up in diatom cell density and chl a concentration ended, while the POC concentration continued to increase until nitrate exhaustion (Day 9, Fig. 3A, B). This rise in [POC] was paralleled by a near doubling in the $\mathrm{C} / \mathrm{N}$ ratio of phytoplankton organic matter (Fig. 3C). Such an increase in the phytoplankton $\mathrm{C} / \mathrm{N}$ ratio is typical for nitrogen-limited phytoplankton (Banse 1974, 1994, Sakshaug \& HolmHansen 1977), and indicates phytoplankton bloom termination due to nitrate depletion (see Sakshaug et al. 1983, Sakshaug \& Olsen 1986 for a comprehensive treatment of nutrients limiting phytoplankton blooms in Norwegian fjords).

\section{Carbon isotope composition}

$\delta^{13} \mathrm{C}$ of the $<20 \mu \mathrm{m}$ size fraction was consistently lighter by ca $2 \%$ than that of the $>20 \mu \mathrm{m}$ fraction. This offset may be due to the different phytoplankton taxonomic groups in each size class. Whereas the smaller fraction mostly contained naked flagellates, the larger one was completely dominated by the diatom Skeletonema costatum. Previous observations have shown planktonic diatoms to be isotopically heavier than flagellates under identical environmental conditions (Wong \& Sackett 1978, Gearing et a). 1984, Goering et al. 1990, Fry \& Wainright 1991). Possible reasons for heavy diatom $\delta^{13} \mathrm{C}$ could be higher growth rates (Banse 1982, Fry \& Wainright 1991), as well as a generally larger cell size and carbon content per cell, leading to higher carbon demand of diatoms compared to other taxonomic groups (e.g. Laws et al. 1995, Rau et al. 1996).

The difference in $\delta^{13} \mathrm{C}$ between the 2 size fractions also explains part of the ca 5 rise in $\delta^{13} \mathrm{C}$-POC total observed over the course of the bloom. At the onset of the bloom the isotopically lighter $<20 \mu \mathrm{m}$ fraction contributed $>80 \%$ to the POC. This fraction decreased to $<30 \%$ of POC towards the peak of the bloom (Fig. 3B). A 3 to $5 \%$ shift in $\delta^{13} \mathrm{C}$-POC during spring bloom conditions was also found by Cifuentes et al. (1988) in the Delaware estuary, USA, by Nakatsuka et al. (1992) in a mesocosm experiment, and by Rau et al. (1992) during the JGOFS North Atlantic Bloom Experiment. Over the first half of the study of Rau et al. (1992) $\delta^{13} \mathrm{C}$-POC decreased from -22.9 to $-19.9 \%$. At the same time the diatom to prymnesiophyte pigment ratio shifted from 0.7 to 2. A similar change in the relative ratio of diatom to flagellate POC occurred during Days 4 to 7 in this study, with a corresponding $2.4 \%$ change in $\delta^{13} \mathrm{C}$ of total POC. The $\delta^{13} \mathrm{C}$ of the diatom size fraction increased by only $1.6 \%$ over this period (Fig. $4 \mathrm{C}$ ), suggesting that the potential effect of changing environmental conditions (e.g. $\mathrm{CO}_{2}$ concentration) on phytoplankton isotopic composition would have been significantly overestimated if based on changes in $\delta^{13} \mathrm{C}$ of total POC

\section{Carbon isotope fractionation}

$\varepsilon_{\mathrm{p}}$ of the diatom size class (POC $>20 \mathrm{~m}$ ) steadily decreased during the period of exponential growth (Fig. 5A, Days 1 to 7 ) and leveled off after the peak in cell density and chl a concentration. Decreasing $\varepsilon_{p}$ closely corresponds to a concomittant decline in surface water $\mathrm{CO}_{2}(\mathrm{aq})$ concentration (Fig. 5B), suggesting that molecular $\mathrm{CO}_{2}$, at least in part, served as the source of inorganic carbon utilized by the phytoplankton.

Deviation of the isotopic signal from the correlation of $\varepsilon_{\mathrm{p}}$ with $\left[\mathrm{CO}_{2}(\mathrm{aq})\right]$ obtained during bloom development occurred after Day 8. Since chl a concentrations and Skeletonema costatum cell numbers started to level off at this point, this deviation may reflect a drop in phytoplankton growth rates. However, $\mathrm{POC}_{>20} \mathrm{\mu m}$ further increased until Day 10 (Fig. 3B), indicating that photosynthetic carbon fixation continued at about the same rate for another $2 \mathrm{~d}$. During Days 9 and $10, \varepsilon_{\mathrm{p}}$ should, therefore, be expected to roughly follow the trend of the previous days. On the other hand, on these days phytoplankton growth was evidently nitrate-limited (Fig. 2D). In a comparison of $\varepsilon_{p}$ responses of a marine diatom obtained in nitrate-replete batch cultures and nitrate-limited chemostat cultures we have observed a large offset in isotope fractionation between the 2 approaches, with higher $\varepsilon_{\mathrm{p}}$ values for $\mathrm{N}$ limited cells (Riebesell et al. unpubl.). Based on this finding, the observed deviation from the $\varepsilon_{p}$ versus $\left[\mathrm{CO}_{2}(\mathrm{aq})\right]$ correlation, which yielded higher $\varepsilon_{\mathrm{p}}$ values under nitrate-limiting conditions than expected for the corresponding $\mathrm{CO}_{2}(\mathrm{aq})$ concentrations, may also be interpreted as the result of a shift from nitrate-replete to nitrate-limited growth.

The relationship between $\varepsilon_{\mathrm{p}}$ and $\mu_{\mathrm{i}} /\left[\mathrm{CO}_{2}(\mathrm{aq})\right]$ obtained for the $>20 \mu \mathrm{m}$ size fraction dominated by Skeletonema costatum largely agrees with experimental results of Hinga et al. (1994) for the same species (Fig. 6A). These authors grew $S$, costatum in dilute batch cultures at different $\mathrm{CO}_{2}(\mathrm{aq})$ concentrations and 
growth rates. The 2 data sets differ from each other at low $\left[\mathrm{CO}_{2}(\mathrm{aq})\right]$ \{i.e. high values of $\left.\mu_{\mathrm{i}} /\left[\mathrm{CO}_{2}(\mathrm{aq})\right]\right\}$, where isotope fractionation reported by Hinga et al. (1994) also clearly deviated from a linear $\varepsilon_{\mathrm{p}}$ versus $\mu_{\mathrm{i}} /\left[\mathrm{CO}_{2}(\mathrm{aq})\right]$ correlation. This difference could be related to the fact that calculations from the data set of Hinga et al. (1994) were based on a single growth rate for the entire range of $\mathrm{CO}_{2}$ concentrations in each of the experimental runs (see Table 1 in Hinga et al. 1994). Lower growth rates under low $\left[\mathrm{CO}_{2}(\mathrm{aq})\right]$, for example, could reconcile the observed differences. It should be noted here that $\varepsilon_{\mathrm{p}}$ estimates from field measurements are for total suspended particulate organic matter (i.e. with contributions from heterotrophic organisms and detrital organic material), whereas experimental data correspond to pure algal biomass. An offset of $1.4 \%$ between phytoplankton and bulk particulate organic matter has been estimated by Laws et al. (1995). Applying this offset to the experimental data of Hinga et al. (1994) would lower $\varepsilon_{p}$ values in their data set by this amount.

Comparison of data obtained in this and in the study of Hinga et al. (1994) with previous field investigations (Laws et al. 1995, Dehairs et al. 1997, Popp et al. 1997) in an $\varepsilon_{\mathrm{p}}$ versus $\mu_{1} /\left[\mathrm{CO}_{2}(\mathrm{aq})\right]$ plot shows reasonable agreement between these data sets (Fig, 6B). Still, for any given value of $\mu_{\mathrm{i}} /\left[\mathrm{CO}_{2}(\mathrm{aq})\right], \varepsilon_{\mathrm{p}}$ spans a range of several per mille. Part of this range may be due to different approaches in determining phytoplankton growth rate. Dehairs et al. (1997) measured $\delta^{13} \mathrm{C}$-POC in the Southern Ocean between $47^{\circ}$ and $55^{\circ} \mathrm{S}$ and estimated instantaneous growth rates from carbon-specific production rates $\left(24 \mathrm{~h}{ }^{14} \mathrm{C}\right.$ incubations) corrected for the phytoplankton proportion of total [POC]; $\varepsilon_{\mathrm{p}}$ was calculated assuming a constant $\delta^{13} \mathrm{C}-\mathrm{CO}_{2}(\mathrm{aq})$ of $-10 \%$ (Dehairs et al. 1997). The growth rate in the study of Laws et al. (1995) in the Equatorial Pacific was estimated from $\left[\mathrm{CO}_{2}(\mathrm{aq})\right]$ data using a linear regression between $\mu_{1} /\left[\mathrm{CO}_{2}(\mathrm{aq})\right]$ and $\varepsilon_{\mathrm{p}}$ obtained from $\mathrm{N}$-limited Phaeodactylum tricornutum chemostats, corrected for photoperiodic length and respiration. As discussed below, application of this relationship to carbon isotope data obtained from $\mathrm{N}$-replete natural populations may be problematic. To estimate photoperiodic growth rate, Popp et al. (1997) used Eppley's (1972) growth rate versus temperature relationship and assumed temperature-limited growth for their WOCE SR-3 data cobtained between $45^{\circ}$ and $65^{\circ} \mathrm{S}$ for suspended particulate organic matter). Since this relationship predicts maximum potential growth rates for any given temperature, it is likely to overestimate phytoplankton growth rates in the field. Actual values of $\mu_{1} /\left[\mathrm{CO}_{2}(\mathrm{aq})\right]$ for the data of Popp et al. (1997) are therefore likely to be lower than those plotted in Fig. 6B, which would result in closer agreement with the other results.
As discussed earlier, considerable variability in phytoplankton isotope fractionation may also result from differences in species composition. The fact that this may also have contributed to the large scatter of $\varepsilon_{\mathrm{p}}$ in the comparison of field data presented in Fig. $6 \mathrm{~B}$ is indicated by the data set of Dehairs et al. (1997). For $\mu_{1} /\left[\mathrm{CO}_{2}(\mathrm{aq})\right]$ values of 0.035 to 0.04 , for example, these authors obtained $\varepsilon_{\mathrm{p}}$ values of 14.5 and $18.5 \%$. Whereas the lower value corresponded to a phytoplankton community dominated by diatoms, the high $\varepsilon_{p}$ value was obtained for phytoplankton composed of equal proportions of diatoms, green algae, and prymnesiophytes (Fig. 4 in Peeken 1997). Lower isotope fractionation for diatoms and diatom-dominated phytoplankton is, in fact, consistent with differences in $\delta^{13} \mathrm{C}$ observed between the 2 size fractions in this study, as well as with earlier reports on diatoms being isotopically heavier than other phytoplankton species (e.g. Fry \& Wainright 1991, Pancost et al. 1997).

As previously noted (Pancost et al. 1997, Popp et al. 1997), a considerable offset exists between the bulk of the field estimates and results obtained in culture experiments with the marine diatom Phaeodactylum tricornutum by Laws et al. (1995, dashed line in Fig. 6B). While this offset may be due to species-specific differences in $\varepsilon_{\mathrm{p}}$ responses related to, among other factors, cell size (Rau et al. 1996), cell geometry (Rau et al. 1997, Popp et al. 1998) or carbon acquisition mechanisms (Raven et al. 1993), it may also reflect differences in the nutritional status of the phytoplankton. Whereas experiments by Laws et al. (1995) were conducted in N-limited chemostats. Hinga et al. (1994) used $\mathrm{N}$-replete batch culture incubations. In accordance with the latter study, all field estimates presented in Fig. 6B were determined on particulate organic matter produced under $\mathrm{N}$-replete conditions.

\section{Conclusions}

A steady increase in the carbon isotope composition of total organic matter over the course of the diatom bloom was partly caused by a shift in species composition from a flagellate- to a diatom-dominated community. Isotope fractionation of the $>20 \mu \mathrm{m}$ size fraction, dominated by the diatom Skeletonema costatum, correlated with surface water $\mathrm{CO}_{2}$ concentration over the period of bloom development. Deviation from this correlation occurred after cell density and chl a concentration had peaked and may be related to changes in phytoplankton growth rate and/or possible effects of nitrogen-limited growth on isotope fractionation. Comparison with field data from previous investigations shows general agreement in the presence of an inverse relationship between $\varepsilon_{\mathrm{p}}$ and $\mu_{\mathrm{i}} /\left[\mathrm{CO}_{2}(\mathrm{aq})\right]$, with rela- 
tively good correspondence in the slope of this relationship. However, there is considerable scatter in $\varepsilon_{p}$ for any given ratio of growth rate and $\mathrm{CO}_{2}$ concentration.

The results of this study show that changes in environmental conditions, for example as encountered during the course of a phytoplankton bloom, are imprinted in the carbon isotope composition of the particulate organic matter produced. In addition to $\mathrm{CO}_{2}$ concentration and growth rate, isotope fractionation of marine phytoplankton may also be influenced by taxon-specific differences and the nutritional status of the cells. While taxon-specific biomarkers can help to resolve species-related variability in the isotopic signal, the utility of sedimentary organic matter $\delta^{13} \mathrm{C}$ as a proxy for growth rate or $\left[\mathrm{CO}_{2}(\mathrm{aq})\right]$ may be further complicated by the potential. influence of other environmental factors on phytoplankton isotope fractionation.

Acknowledgements. We thank A. Dauelsberg, J. Engler, C. Hartmann, K.-U. Richter, G. Traue, and A. Mackensen for technical assistance and S. Burkhardt and B. Kroon for fruitful discussions. J. Engler and M. Botros provided helpful comments on earlier versions of this manuscript. This research was partly supported by the project 'Marine Ecosystems Regulation: Trace Metal and Carbon Dioxide Limitations' (MERLIM) of the European Union within the Marine Science and Technology Program under Contract no. MAS3-CT95-0005. This is publication no. 1513 of the Alfred Wegener Institute for Polar and Marine Research.

Helmut Kukert died unexpectedly during the preparation of this manuscript in March 1998. This completed work is dedicated to his memory.

\section{LITERATURE CITED}

Aksnes DL, Lie U (1990) A coupled physical-biological pelagic model of a shallow sill fjord. Estuar Coast Shelf Sci 31:459-486

Almgren T, Dyrssen D, Fonselius S (1988) Determination of alkalinity and total carbonate. In: Grasshoff K, Ehrhardt $\mathrm{M}$, Kremling $\mathrm{K}$ (eds) Methods of seawater analysis, Verlag Chemie, Weinheim, p 99-123

Armstrong FAJ, Stearns CR, Strickland JDH (1967) The measurement of upwelling and subsequent biological processes by means of the Technicon Autoanalyser ${ }^{\text {(s) }}$ and associated equipment. Deep-Sea Res 14:381-389

Banse K (1974) On the interpretation of data for the carbon-tonitrogen ratio of phytoplankton. Limnol Oceanogr 19: $659-699$

Banse K (1982) Cell volumes, maximal growth rates of unicellular algae and ciliates, and the role of ciliates in the marine pelagial. Limnol Oceanogr 27:1059-1071

Banse K (1994) Uptake of inorganic carbon and nitrate by marine plankton and the Redfield ratio. Global Biogeochem Cycles 8:81-84

Berger WH, Wefer G (1990) Export production: seasonality and intermittency, and paleoceanographic implications. Palaeogeogr Palaeoclimatol Palaeoecol 89:245-254

Bidigare RR, Fluegge A, Freeman KH, Hanson KL, Hayes JM, Hollander D, Jasper JD, King LL, Laws LA, Milder J, Millero FJ, Pancost R, Popp BN, Steinberg PA, Wakeham
SG (1997) Consistent fractionation of ${ }^{13} \mathrm{C}$ in nature and in the laboratory: growth-rate effects in some haptophyte algae. Global Biogeochem Cycles 11:279-292

Cifuentes LA, Sharp JH. Fogel ML (1988) Stable carbon and nitrogen isotope biogeochemistry in the Delaware estuary. Limnol Oceanogr 33:1102-1115

Degens ET (1969) Biogeochemistry of stable carbon isotopes In: Eglinton G, Murphy MTJ (eds) Organic geochemistry methods and results. Springer-Verlag, New York, p 304-329

Degens ET, Guillard RR, Sackett WM, Hellebust JA (1968) Metabolic fractionation of carbon isotopes in marine plankton-1. Temperature and respiration experiments. Deep-Sea Res 15:1-9

Dehairs F, Kopczynska E, Nielsen P, Lancelot C. Bakker DCE, Koeve W, Goyens L (1997) $\delta^{13} \mathrm{C}$ of Southern Ocean organic matter during spring and austral early summer: regional and temporal variability. Deep-Sea Res II 44:129-142

Descolas-Gros C, Fontugne M (1990) Stable carbon isotope fractionation by marine phytoplankton during photosynthesis. Plant Cell Environ 13:207-218

Eberlein K, Kattner G (1987) Automatic method for the determination of ortho-phosphate and total dissolved phosphorus in the marine environment. Fresenius $Z$ Anal Chem 326:354-357

Edler L (1979) Recommendations for marine biological studies in the Baltic Sea. Phytoplankton and chlorophyll. Baltic Mar Biol Publ 5:1-38

Eppley RW (1972) Temperature and phytoplankton growth in the sea. Fish Bull 70:1063-1085

Eppley RW, Rogers JN, McCarthy JJ (1969) Half-saturation. constants for uptake of nitrate and ammonium by marine phytoplankton. Limnol Oceanogr 14:912-920

Falkowski PG (1991) Species variability in the fractionation of ${ }^{13} \mathrm{C}$ and ${ }^{12} \mathrm{C}$ by marine phytolpankton. J Plankton Res 13: $21-28$

Fry B, Wainright SC (1991) Diatom sources of ${ }^{13} \mathrm{C}$-rich carbon in marine food webs. Mar Ecol Prog Ser 76:149-157

Gearing JN, Gearing PJ, Rudnick DT, Requejo AC; Hutchins MJ (1984) Isotopic variability of organic carbon in a phytoplankton-based temperate estuary. Geochim Cosmochim Acta 48:1089-1098

Geider RJ, Osborne BA (1989) Respiration and microalgal growth: a review of the quantitative relationship between dark respiration and growth. New Phytol 112:327-342

Goering J, Alexander V, Haubenstock H (1990) Seasonal variability of stable carbon and nitrogen isotope ratios of organisms in a North Pacific bay. Estuar Coast Shelf Sci 30:239-260

Goyet C. Poisson A (1989) New determination of carbonic acid dissociation constants in seawater as a function of temperature and salinity. Deep-Sea Res 36(11): $1635-1654$

Grasshoff K, Ehrhardt M, Kremling K (1983) Methods of seawater analysis. Verlag Chemie, Weinheim

Guy RD, Fogel ML, Berry JA (1993) Photosynthetic fractionation of the stable isotopes of oxygen and carbon. Plant Physiol 101:37-47

Hinga KR, Arthur 'JA, Pilson MEQ. Whitaker D (1994) Carbon isotope fractionation by marine phytoplankton in culture: the effects of $\mathrm{CO}_{2}$ concentration, $\mathrm{pH}$, temperature, and species. Global Biogeochem Cycles 8:91-102

Johnson KM, Sieburth JMcN, Williams PJleB, Brändström L (1987) Coulometric total carbon dioxide analysis for marine studies: automation and calibration. Mar Chem 21: $117-133$

Johnston AM (1996) The effect of environmental variables on 
${ }^{13} \mathrm{C}$ discrimination by two marine phytoplankton. Mar Ecol Prog Ser 132:257-263

Korb RE, Raven JA, Johnston AM, Leftley JW (1996) Effects of cell size and specific growth rate on stable carbon isotope discrimination by two species of marine diatom. Mar Ecol Prog Ser 143:283-288

Kreyszig E (1982) Statistische Methoden und ihre Anwendungen, 7 th edn. Vandenhoeck and Ruprecht, Göttingen

Lännergren C, Skjoldal HR (1976) The spring phytoplankton bloom in Lindåspollene, a land-locked Norwegian fjord. Autotrophic and heterotrophic activities in relation to nutrients. In: Persoone G, Japsers E (eds) Population in dynamics of marine organisms in relation with nutrient cycling in shallow waters. Proc 10 th Eur Symp Mar Biol, Ostend, 17-23 September 1975. Universa Press, Wettren, p 363-391

Laws EA, Bannister TT (1980) Nutrient- and light-limited growth of Thalassiosira fluviatilis in continuous culture, with implications for phytoplankton growth in the ocean. Limnol Oceanogr 25:457-473

Laws EA, Popp BN, Bidigare RR (1997) Effect of growth rate and $\mathrm{CO}_{2}$ concentration on carbon isotopic fractionation by the marine diatom Phaeodactylum tricornutum. Limnol Oceanogr 42:1552-1560

Laws EA, Popp BN, Bidigare RR, Kennicutt MC, Macko SA (1995) Dependence of phytoplankton carbon isotopic composition on growth rate and $\left[\mathrm{CO}_{2}\right]$ aq: theoretical considerations and experimental results. Geochim Cosmochim Acta 59:1131-1138

Leboulanger C, Descolas-Gros C, Fontugne MR, Bentaleb I, Jupin $H$ (1995) Interspecific variability and environmental influence on particulate organic carbon $\delta^{13} \mathrm{C}$ in cultured marine phytoplankton. J Plankton Res 17:2079-2091

Mackensen A, Hubberten HW, Scheele N, Schlitzer R (1996) Decoupling of $\delta^{13} \mathrm{C} \mathrm{CO}_{2}$ and phosphate in recent Weddell Sea deep and bottom water: implications for glacial Southern Ocean paleoceanography. Paleoceanography 11(2): 203-215

Mizutani $\mathrm{H}$, Wada $\mathrm{E}$ (1982) Effect of high atmospheric $\mathrm{CO}_{2}$ concentration on $\delta^{13} \mathrm{C}$ of algae. Origins Life 12:377-390

Nakatsuka T, Handa N, Wada E, Wong CS (1992) The dynamic changes of stable isotopic ratios of carbon and nitrogen in suspended and sedimented particulate organic matter during a phytoplankton bloom. J Mar Res 50:267-296

Pancost RD, Freeman KH, Wakeham SG, Robertson CY (1997) Controls on carbon isotope fractionation by diatoms in the Peru upwelling region. Geochim Cosmochim Acta 61:4983-4991

Pardue JW, Scalan RS, Van Baalen C, Parker PL (1976) Maximum carbon isotope fractionation in photosynthesis by blue-green algae and a green alga. Geochim Cosmochim Acta 40:309-312

Park R, Epstein S (1960) Carbon isotope fractionation during photosynthesis. Geochim Cosmochim Acta 21:110-126

Peeken I (1997) Photosynthetic pigment fingerprints as indicators of phytoplankton biomass and development in different water masses of the Southern Ocean during austral spring. Deep-Sea Res 44:261-282

Popp BN, Laws EA, Bidigare RR, Dore JE, Hanson KL, Wakeham SG (1998) Effect of phytoplankton cell geometry on carbon isotopic fractionation. Geochim Cosmochim Acta 62:69-77

Popp BN, Parekh P, Tilbrook B, Bidigare RR, Laws EA (1997)

Editorial responsibility: Otto Kinne (Editor), Oldendort/Luhe, Germany
Organic carbon $\delta^{13} \mathrm{C}$ variations in desimentary rocks as chemostratigraphic and paleoenvironmental tools. Palaeogeogr Palaeoclimatol Palaeoecol 132:119-132

Rau GH, Riebesell U, Wolf-Gladrow D (1996) A model of photosynthetic ${ }^{13} \mathrm{C}$ fractionation by marine phytoplankton based on diffusive molecular $\mathrm{CO}_{2}$ uptake. Mar Ecol Prog Ser 133:275-285

Rau GH, Riebesell U, Wolf-Gladrow D (1997) $\mathrm{CO}_{2}$ aq-dependent photosynthetic ${ }^{13} \mathrm{C}$ fractionation in the ocean: a model versus measurements. Global Biogeochem Cycles $11: 267-278$

Rau GH, Takahashi T, Des Marais DJ (1989) Latitudinal variations in plankton $\delta^{13} \mathrm{C}$ : implications for $\mathrm{CO}_{2}$ and productivity in past oceans. Nature 341:516-518

Rau GH, Takahashi T, Des Marais DJ, Repeta DJ, Martin JH (1992) The relationship between $\delta^{13} \mathrm{C}$ of organic matter and $\left[\mathrm{CO}_{2}(\mathrm{aq})\right]$ in ocean surface water: data from JGOFS site in the northeast Atlantic Ocean and a model. Geochim Cosmochim A.cta 56:1413-1419

Raven JA, Johnston AM, Turpin DH (1993) Influence of changes in $\mathrm{CO}_{2}$ concentration and temperature on marine phytoplankton ${ }^{13} \mathrm{C} /{ }^{12} \mathrm{C}$ ratios: an analysis of possible mechanisms. Global Planet Change 8:1-12

Robinson JJ, Cavanaugh CM (1995) Expression of form I and form II Rubisco in chemoautotrophic symbioses: implications for the interpretation of stable carbon isotope values. Limnol Oceanogr 40:1496-1502

Sætre R, Aure J, Ljøen R (1988) Wind effects on the lateral extension of the Norwegian Coastal Water. Cont Shelf Res 8:239-253

Sakshaug E. Andresen K, Myklestad S, Olsen Y (1983) Nutrient status of phytoplankton communities in Norwegian waters (marine, brackish, and fresh) as revealed by their chemical composition. J Plankton Res 5:175-196

Sakshaug E, Holm-Hansen O (1977) Chemical composition of Skeletonema costatum (Grev.) Cleve and Pavlova (Monochrysisj Lutheri (Droop) Green as a function of nitrate-, phophate-, and iron-limited growth. J Exp Mar Biol Ecol 29:1-34

Sakshaug E, Olsen Y (1986) Nutrient status of phytoplankton blooms in norwegian waters and algal strategies for nutrient competition. Can J Fish Aquat Sci 43:389-396

Sharkey TD, Berry JA (1985) Carbon isotope fractionation of algae as influenced by an inducible $\mathrm{CO}_{2}$ concentrating mechanism. In: Lucas WJ, Berry JA (eds) Inorganic carbon uptake by aquatic photosynthetic organisms. Am Soc Plant Physiol, Rockville, MD, p 389-401

Takahashi K, Wada E, Sakamoto M (1991) Relationship between carbon isotope discrimination and the specific growth rate of green alga Chlamydomonas reinhardtii. Jpn J Limnol 52:105-112

Utermöhl H (1958) Zur Vervallkommnung der quantitativen Phytoplankton-Methodik. Mitt Int Ver Theor Angew Limnol 9:1-38

Wassmann P (1983) Sedimentation of organic and inorganic particulate material in Lindåspollene, a stratified, landlocked fjord in western Norway. Mar Ecol Prog Ser 13: $237-248$

Wong WW, Sackett WM (1978) Fractionation of stable carbon isotopes by marine phytoplankton. Geochim Cosmochim Acta 42:1809-1815

Zhang J, Quay PD, Wilbur DO (1995) Carbon isotope fractionation during water-gas exchange and dissolution of $\mathrm{CO}_{2}$. Geochim Cosmochim Acta 59:107-114

Submitted: April 14, 1998; Accepted: August 3, 1998

Proofs received from author(s): October 22, 1998 